\title{
Manajemen Anestesi pada Wanita Hamil dengan Eklampsia dan Asma Akut Berat yang Menjalani Seksio Sesarea
}

\author{
Erna Fitriana Alfanti ${ }^{1}$, Ratih Kumala FA ${ }^{2}$, Yusmein Uyun ${ }^{2}$ \\ ${ }^{1}$ Departemen Anestesiologi dan Terapi Intensif RSUD Kraton Pekalongan, ${ }^{2}$ Departemen Anestesi dan Terapi \\ Intensif Fakultas Kedokteran Universitas Gadjah Mada-RSUP Dr. Sardjito, Daerah Istimewa Yogyakarta
}

\begin{abstract}
Abstrak
Eklampsia dengan asma merupakan kondisi medis yang paling sering terjadi dalam kehamilan. Eklampsia dengan asma akut berat dalam kehamilan merupakan problem yang sulit. Kejadian eklampsia sekitar 2-8\% diseluruh dunia dan merupakan penyebab kematian tertinggi kedua setelah perdarahan. Prevalensi terjadinya $0,3 \%-0,7 \%$ pada negara berkembang. Asma merupakan penyakit inflamasi kronis saluran nafas yang melibatkan banyak sel dan elemen seluler yang mengakibatkan terjadinya hiperresponsif jalan nafas yang dapat menimbulkan gejala episodik berulang berupa wheezing, sesak nafas, dada berat dan batuk. Di Indonesia prevalensi berkisar 5-6\% dari populasi penduduk, dimana serangan asma biasanya timbul pada usia kehamilan 24-36 minggu. Seorang wanita 28 tahun G1P0A0 datang hamil 35 minggu dengan keluhan sesak, nyeri kepala, kejang tiga kali, kaki bengkak. Dilakukan seksio sesarea dengan anestesi umum. Ventilator mekanik selama seksio sesarea harus disesuaikan untuk menjaga $\mathrm{PCO}_{2} 30-32 \mathrm{mmHg}$. Intubasi dilakukan dengan rapid sequence induction dan setelah pipa endotrakheal masuk dijaga tekanan darah supaya tidak meningkat. Setelah operasi selesai dilakukan ekstubasi dalam untuk mencegah gejolak hemodinamik dan mengurangi iritasi saluran nafas. Pasca operasi pasien masuk intensive care unit untuk pemantauan lebih lanjut. Penanganan anestesi yang efektif pada pasien ini akan meningkatkan survival serta memberikan prognosis yang lebih baik
\end{abstract}

Kata kunci: asma akut berat; anestesi umum; eklampsia; kehamilan

\section{Management of Anesthesia in Caesarean Section for Patient with Eclampsia and Severe Acute Asthma}

\begin{abstract}
Eclampsia with asthma is the most common medical condition in pregnancy. Eclampsia with severe acute asthma in pregnancy is a difficult problem. The incidence of eckampsia is around $2-8 \%$ worldwide and is the second highest cause of death after bleeding. The prevalence of occurrence is $0.3 \%-0.7 \%$ in developing countries. Asthma is a chronic inflammatory airway disease that involves many cells and cellular elements that cause airway hyperresponsiveness which can cause recurrent episodic symptoms such as wheezing, shortness of breath, heavy chest and coughing. In Indonesia the prevalence ranges from 5-6\% of the population, where asthma attacks usually occur at 24-36 weeks' gestation. A 28-year-old woman G1P0A0 comes 35 weeks pregnant with complaints of tightness, headache, seizures three times, swollen feet. Caesarean section was performed under general anesthesia. Mechanical ventilator during cesarean section must be adjusted to maintain $\mathrm{PCO}_{2}$ 30-32 $\mathrm{mmHg}$. Intubation was done by rapid sequence induction and after the endotracheal tube has been entered, the intracranial pressure is maintained so it did not increase. After the operation was complete, extubation was done to prevent hemodynamic fluctuations and reduce airway irritation. Postoperatively the patient was admitted to the intensive care unit for further monitoring. Effective anesthetic treatment in these patients will increase survival and provide a better prognosis
\end{abstract}

Key words: General anesthesia; Severe acute asthma eclampsia; pregnancy 


\section{Pendahuluan}

Eklampsia didefinisikan sebagai peristiwa terjadinya kejang pada kehamilan $\geq 20$ minggu disertai atau tanpa penurunan tingkat kesadaran bukan karena epilepsi maupun gangguan neurologi lainnya. ${ }^{1}$ Kejadian eklampsia sekitar 2-8\% diseluruh dunia dan merupakan penyebab kematian tertinggi kedua setelah perdarahan., ${ }^{2,3}$ Angka kejadian eklampsia di Indonesia mencapai 128.273 kasus setiap tahun. Eklampsia paling sering terjadi pada trimester ketiga dan menjadi sering saat kehamilan mendekati aterm. Prevalensi terjadinya $0,3 \%-0,7 \%$ pada negara berkembang. ${ }^{4}$ Asma merupakan penyakit inflamasi kronis saluran nafas yang melibatkan banyak sel dan elemen seluler yang mengakibatkan terjadinya hiperresponsif jalan nafas yang dapat menimbulkan gejala episodik berulang berupa wheezing, sesak nafas, dada berat dan batuk. ${ }^{5}$ Pada tahun 2018 angka prevalensi ibu hamil dengan asma didunia berkisar $1-1,8 \%$. Di Indonesia prevalensi berkisar $5-6 \%$ dari populasi penduduk, dimana serangan asma biasanya timbul pada usia kehamilan 24-36 minggu. ${ }^{6}$ Morbiditas dan mortalitas pasien hamil dengan asma meningkat 2001-2010 dari $7,3 \%$ menjadi $8,4 \%$ didunia, dan merupakan penyebab kematian no 4 di Indonesia yaitu sebesar 5,6\%. ${ }^{7}$ Penyakit asma yang tidak dikelola dengan baik pada ibu hamil dapat meningkatkan risiko bayi premature atau bayi lahir dengan berat badan rendah. Oleh karena itu, ibu hamil disarankan mengelola penyakitnya, salah satunya dengan menghindari faktor pencetus asma. ${ }^{7}$

\section{Kasus}

\section{Anamnesa}

Seorang wanita 28 tahun G1P0A0 datang rujukan rumah sakit ke unit gawat darurat RSUD Kraton Pekalongan (alasan dirujuk karena rumah sakit tidak punya intensive care unit) hamil 35 minggu dengan keluhan sesak $(+)$, nyeri kepala $(+)$, kejang satu kali, kaki bengkak(+), mata kabur(+), nyeri ulu hati(+), kontraksi(-), keluar air dari vagina(-), gerak janin dirasakan aktif. Diketahui mempunyai tekanan darah tinggi baru di rumah sakit awal dan selama ini ante natal care (ANC) di bidan dekat rumah. Riwayat alergi: ikan, riwayat sakit sistemik: asma $(+)$ diobati dengan salbutamol spray selama hamil 3 kali kumat dan memakai salbutamol spray, makan terakhir: 2 jam sebelum ke RS dan minum 30 menit yang lalu. Saat ini pasien mendapat terapi infus RL $30 \mathrm{tpm}+$ bolus 6 gram $\mathrm{MgSO} 4$ iv

\section{Pemeriksaan Fisik}

Kesadaran : somnolen, GCS E3M5V3, tekanan darah: 180/110 mm $\mathrm{Hg}$, nadi: $120 \mathrm{x} / \mathrm{mnt}$, laju nafas: $40 \mathrm{x} / \mathrm{mnt}$, berat badan: $80 \mathrm{~kg}$, tinggi badan: $160 \mathrm{~cm}, \mathrm{SpO}_{2}: 90 \%$, masker rebreathing 8 lt/menit, mata: pupil edema $(+) /(+)--)$ dokter spesialis mata, dada: payudara simetris, wheezing di kedua lapangan paru, ronkhi (-) /(-), nyeri epigastrium: $+($ skala nyeri 7-8 ), abdomen: bising usus normal, tinggi fundus uteri (TFU) sesuai kehamilan, denyut jantung janin (DJJ): $158 \mathrm{x} /$ menit, ekstremitas: tungkai edema $(+) /(+)$ sejak kehamilan 26 minggu, perdarahan: tidak ada tanda perdarahan.

\section{Pemeriksaan Penunjang}

Tabel 1. Hasil Laboratorium

\begin{tabular}{lll}
\hline $\begin{array}{l}\text { hasil } \\
\text { laboratorium }\end{array}$ & nilai & nilai normal \\
$\mathrm{Hb}$ & $8,7 \mathrm{~g} / \mathrm{dl}$ & $12-16 \mathrm{~g} / \mathrm{dl}$ \\
$\mathrm{Ht}$ & $28,8 \%$ & $37-47 \%$ \\
Leukosit & $9,9910^{\wedge} 3 / \mathrm{ul}$ & $4,80-10,8010^{\wedge} 3 / \mathrm{ul}$ \\
Trombosit & 229000 & $150.000-450.000$ \\
$\mathrm{MCV}$ & $76,20 \mathrm{um} 3$ & $78-102 \mathrm{um} 3$ \\
$\mathrm{MCH}$ & $23.00 \mathrm{pg}$ & $25-35 \mathrm{pg}$ \\
$\mathrm{MCHC}$ & $30,20 \mathrm{~g} / \mathrm{dl}$ & $31-37 \mathrm{~g} / \mathrm{dl}$ \\
$\mathrm{RDW}-\mathrm{CV}$ & $26,9 \%$ & $11,5-14,5 \%$ \\
$\mathrm{RDW}-\mathrm{SD}$ & $69,3 \%$ & $35-47 \%$ \\
SGOT & 25,4 & $<31$ \\
SGPT & 17,3 & $<34$ \\
Ureum & 19,2 & $17-49$ \\
Creatinin & 0,60 & $0,60-1$ \\
\hline
\end{tabular}

Waktu perdarahan: 3 menit ( $1-3$ ), waktu pembekuan: 4 menit 30 detik ( 3-7 ), Hbs Ag: negatif, protein bebas: positif $2(+2)$, Kejang di unit gawat darurat (UGD) berulang 3 kali 
Pengelolaan Anestesi

Assesment:

Gravida

Eklampsia

Asma Akut Berat

Anemia

Status Fisik ASA III E

\section{Persiapan Pra Anestesi}

Persiapan di unit gawat darurat (UGD): memberikan penjelasan kepada keluarga tentang rencana anestesi yang akan dilakukan mulai dari ruang penerimaan, ruang operasi sampai ruang intensive care unit (ICU) untuk pasca operasi, pasang infus dan oksigen disertai konsul dokter spesialis kandungan, puasa sejak sekarang. Dokter spesialis kandungan menginstruksikan protab eklampsia yaitu: diazepam $1 \mathrm{amp}$ iv, methyldopa $250 \mathrm{mg} / 8 \mathrm{jam}$ po, nifedipin $10 \mathrm{mg}$ po, mgSO4 6 gram 28 tpm diteruskan, persiapan untuk akhiri persalinan dengan seksio sesarea. Dokter spesialis paru: ranitidin untuk mengurangi nyeri epigastrium $1 \mathrm{amp} / 8 \mathrm{jam}$ iv, kortikosteroid diberikan methylprednisolone $125 \mathrm{mg}$ iv single dose, aminophylin 1 ampul drip $500 \mathrm{ml} \mathrm{NaCL} 30$ tpm.

\section{Persiapan di Kamar Operasi}

Diputuskan dilakukan seksio sesarea dengan anestesi umum. Evaluasi ulang status present pasien skor glasgow coma scale (GCS) pasien E3M5V2, laju nafas $40 \mathrm{x} / \mathrm{mnt}$, nadi $140 \mathrm{x} / \mathrm{menit}$, denyut jantung janin (DJJ) 160x/menit, kejang terakhir di kamar bersalin (total kejang 3 kali).

Setelah tim operasi siap, masukkan pasien ke dalam kamar operasi, drapping area operasi dahulu supaya delivery obat anestesi ke bayi seminimal mungkin. Siapkan mesin anestesi, monitor, obat untuk anestesia umum.

\section{Teknik Anestesi: Anestesi Umum dengan Rapid} Sequence Induction (RSI)

Induksi menggunakan propofol $2 \mathrm{mg} / \mathrm{kgbb}$, rocuronium $1 \mathrm{mg} / \mathrm{kgbb}$, fentanyl $2 \mathrm{micro} / \mathrm{kgbb}$, drip aminofilin dilanjutkan $30 \mathrm{tpm}$. Pasien dilakukan pre oksigenasi dengan oksigen 6 liter /menit Oksigenasi dan ventilasi memakai sungkup dengan posisi kepala head up. Masukkan premedikasi metoclopramide $10 \mathrm{mg}$ iv, dilakukan preoksigenasi $\mathrm{O}_{2} 8 \mathrm{lt} /$ menit 100 persen tanpa dipompa masih spontan. Dilakukan intubasi sembari operasi dimulai dilakukan sellick maneuver mengurangi risiko muntah

Tabel 2. Monitoring Pasien di Intensive Care Unit (ICU)

\begin{tabular}{|c|c|c|}
\hline Parameter & ICU hari ke-1 & ICU hari ke-2 \\
\hline Tekanan darah $(\mathrm{mmHg})$ & $140 / 80 \mathrm{mmHg}$ & $130 / 80 \mathrm{mmHg}$ \\
\hline Nadi (x/menit) & $95 \mathrm{x} /$ menit & 80x/menit \\
\hline Laju nafas (x/menit) & $20 \mathrm{x} / \mathrm{menit}$ & $16 \mathrm{x} / \mathrm{menit}$ \\
\hline SSP & Reflek patella menurun & Reflek patella normal \\
\hline Pupil & isokor $3 \mathrm{~mm} / 3 \mathrm{~mm}$ & isokor $3 \mathrm{~mm} / 3 \mathrm{~mm}$ \\
\hline Paru & wheezing minimal & wheezing -/- \\
\hline Gastrointestinal & bising usus $(+)$, distensi (-) & bising usus $(+)$, distensi(-) \\
\hline Produksi urin & $0,8 \mathrm{cc} / \mathrm{kg} / \mathrm{jam}$ & $1 \mathrm{cc} / \mathrm{kg} / \mathrm{jam}$ \\
\hline Terapi & $\begin{array}{l}\text { 1. cefotaxim } 1 \mathrm{gram} / 8 \mathrm{jam} \text { iv } \\
\text { 2. MgSo4 } 1 \text { gram } / 24 \text { jam syring- } \\
\text { pump } \\
\text { 3. Aminophilin } 1 \mathrm{ampul} / 500 \mathrm{ml} \\
\text { Nacl } 30 \text { tpm } \\
\text { 4. Fentanyl } 2 \mathrm{ampul} / 500 \mathrm{ml} \\
\text { Nacl } 30 \mathrm{tpm} \\
\text { 5. Paracetamol } 1 \mathrm{gr} / 8 \mathrm{jam} \text { iv }\end{array}$ & $\begin{array}{l}\text { 1. cefotaxim } 1 \text { gram } / 8 \mathrm{jam} \text { iv } \\
\text { 2. MgSo4 --> stop } \\
\text { 3. Aminophilin --> stop } \\
\text { 4. Fentanyl } 2 \text { ampul } / 500 \mathrm{ml} \\
\text { Nacl } 30 \text { tpm }\end{array}$ \\
\hline
\end{tabular}


Tabel 3. Pengelolaan Eklampsia

ALUR PENG ELOLAAN PENDERITA PREEKLAMSIA BERAT/ EKLAMSIA

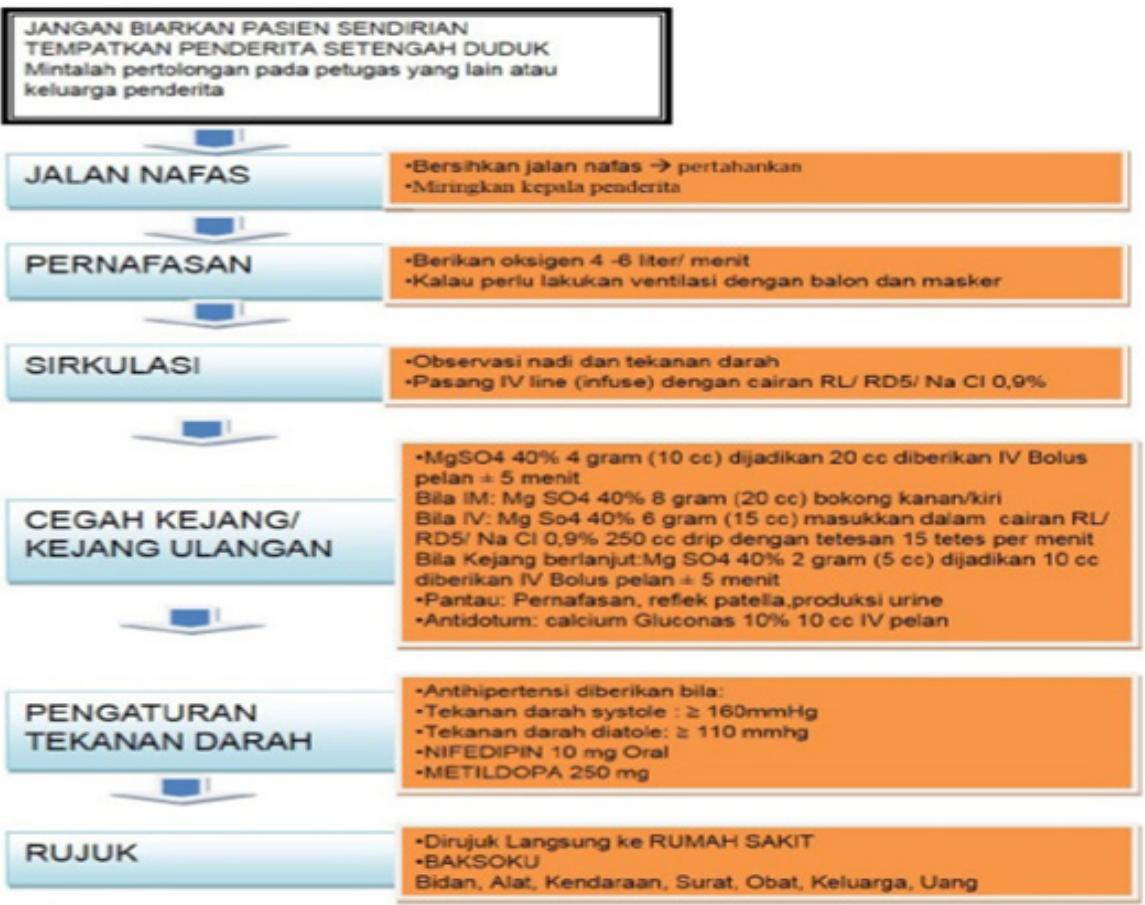

Dikutip dari Morgan GE dan Yarnell RW ${ }^{8,9}$

Tabel 4. Serangan Asma Akut

\begin{tabular}{|c|c|c|c|c|}
\hline \multirow[b]{2}{*}{ Gejala dan Tenda } & \multicolumn{3}{|c|}{ Berat Serangan Akut } & \multirow[t]{2}{*}{ Keadaan mengancam Jiwa } \\
\hline & Ringan & Sedang & Berat & \\
\hline Sesak napas & Berjalan & Berbicara & Istirahat & \\
\hline Posisi & $\begin{array}{l}\text { Dapat tidur } \\
\text { terlentang }\end{array}$ & Membungkuk & Duduk membungkuk & \\
\hline Cara bicara & Satu kalimat & Beberapa kata & Kata demi kata & \\
\hline Kesadaran & Mungkin gelisah & Gelisah & $\begin{array}{l}\text { Mengantuk, gelisah, } \\
\text { kesadaran menurun }\end{array}$ & \\
\hline Frekuensi napas & $<20 /$ menit & 20-30 / menit & $>30 /$ menit & \\
\hline Nadi & $<100$ & $100-200$ & $>120$ & Bradikarda \\
\hline $\begin{array}{l}\text { Pulsus } \\
\text { Paradoksusu }\end{array}$ & $-10 \mathrm{mmHg}$ & $\begin{array}{l}+/-10-20 \\
\mathrm{mmHg}\end{array}$ & $+>25 \mathrm{mmHg}$ & Kelelahan otot \\
\hline $\begin{array}{l}\text { Otot bantu napas } \\
\text { dan retraksi }\end{array}$ & - & + & + & Torakoabdominal paradoksal \\
\hline Mengi & $\begin{array}{l}\text { Akhir ekspirasi } \\
\text { paksa }\end{array}$ & $\begin{array}{l}\text { Akhir } \\
\text { ekspirasi }\end{array}$ & $\begin{array}{l}\text { Inspirasi dan eksip- } \\
\text { irasi }\end{array}$ & Silent chest \\
\hline $\mathrm{APE}$ & $80 \%$ & $60-80 \%$ & $<60 \%$ & \\
\hline $\mathrm{PaO}_{2}$ & $>80 \mathrm{mmHg}$ & $80-60 \mathrm{mmHg}$ & $<60 \mathrm{mmHg}$ & \\
\hline $\mathrm{PaCO}_{2}$ & $<45 \mathrm{mmHg}$ & $<45 \mathrm{mmHg}$ & $>45 \mathrm{mmHg}$ & \\
\hline $\mathrm{SaO}_{2}$ & $>95 \%$ & $91-95 \%$ & $<95 \%$ & \\
\hline
\end{tabular}

Dikutip dari Dixon JM dan Gunning KEJ ${ }^{10}$ 
menggunakan propofol $2 \mathrm{mg} / \mathrm{kgbb}$, rocuronium $1 \mathrm{mg} / \mathrm{kgbb}$, fentanyl $2 \mathrm{micro} / \mathrm{kgbb}$. Intubasi dengan endotracheal no 7 cuff, rumatan gas menggunakan sevoflurane 1,5 -2 MAC sesuai tanda vital, rocuronium $0,5 \mathrm{mg} / \mathrm{kgbb}$, fentanyl 1 micro/kgbb iv. Pasca intubasi dilakukan evaluasi, tensi $140 / 80$, nadi $100 \mathrm{x} / \mathrm{menit}$, saturasi $\mathrm{O}_{2} 98 \%$, wheezing minimal, masih dengan drip aminofilin 20 tts/mnt, drip MgSO4 distop durante operasi. Cairan menggunakan ringer laktat $1000 \mathrm{mg}$ dan packed red cell (PRC) masuk 1 kolf durante operasi. Lahir bayi laki-laki 2,3 kg, panjang bayi
$46 \mathrm{~cm}$, skor APGAR. ${ }^{6-7-8}$ Setelah operasi selesai dilakukan ekstubasi dalam untuk mencegah gejolak hemodinamik dan mengurangi iritasi saluran nafas. Pasca operasi pasien masuk ICU untuk pemantauan lebih lanjut.

\section{Pengelolan Pascabedah}

Pasca operasi masuk intensive care unit (ICU) Permasalahan: ASA III : eklampsia + asma akut berat. Teknik anestesia: anestesia umum dengan rapid sequence induction (RSI). BB: $80 \mathrm{~kg}$, TB: $160 \mathrm{~cm}$.

Tabel 4. Penatalaksanaan Serangan Asma Akut Berat

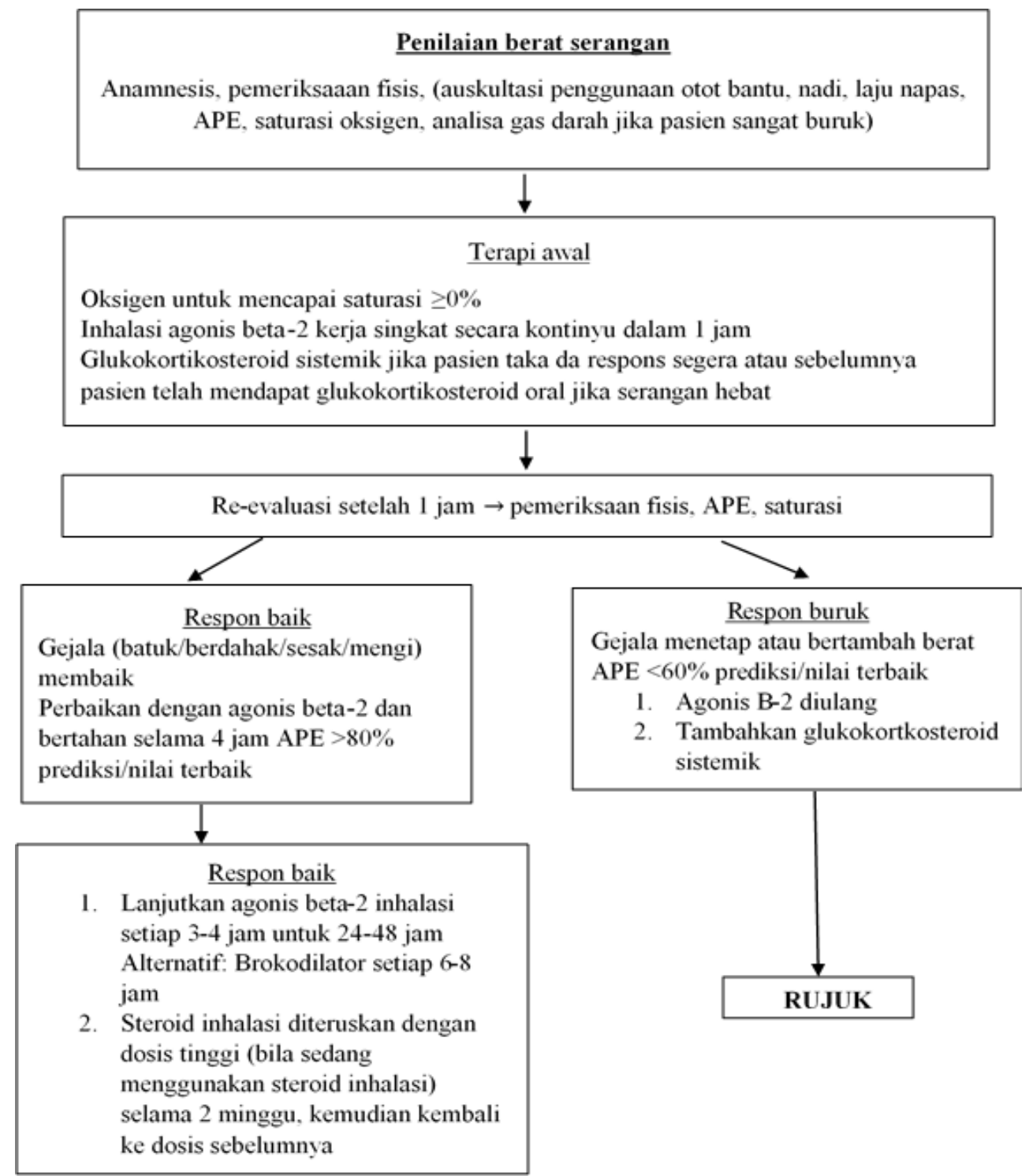

Dikutip dari Dixon JM dan Gunning KEJ ${ }^{10}$ 


\section{Pembahasan}

Penatalaksanaan pasien eklampsia dengan asma akut berat ini yaitu selalu mengingat kosep gawat darurat airway, breathing, circulation (ABC).

Pertama beri oksigen 4-6 liter/menit untuk mengatasi hipoksemia dan asidemia, juga dibutuhkan perawatan kejang untuk melindungi pasien dari kemungkinan cedera serius, pasang infus untuk memasukkan obat dan persiapan operasi, pasang kateter urine untuk mengecek produksi urine per jam. Kemudian diberikan obat untuk memotong kejang yaitu diazepam 1 ampul $10 \mathrm{mg}$ intravena memiliki onset satu menit. Obat obatan untuk mengatasi hipertensi pada kehamilan juga diberikan untuk mengontrol tensi pada pasien ini diberikan methyldopa dan nifedipin, disertai pemberian $\mathrm{MgSO} 4$ intramuscular dan drip intravena. Untuk penatalaksanaan asma diberikan aminofilin 1 ampul dalam $500 \mathrm{ml}$ $\mathrm{NaCL} 20$ tetes/mnt untuk mengurangi sesak. Pencegahan risiko aspirasi pneumonia dapat dilakukan dengan membaringkan pasien pada sisi kiri. Monitoring kesadaran dan dalamnya koma memakai glasgow coma scale.

Penanganan pasien eklampsia dengan asma akut berat ini adalah dengan mengakhiri kehamilan tanpa memandang umur kehamilan dan keadaan janin dan persalinan hanya boleh dilakukan apabila keadaan pasien sudah stabil. Rapid sequence induction (RSI) dilakukan untuk mencegah aspirasi isi lambung pada pasien yang tidak puasa. Tantangan pada pasien ini yaitu asma akut berat sehingga sistem respirasi yang harus dihadapi spesialis anestesi selama operasi adalah penanganan jalan nafas pasien sehingga induksi menggunakan obat obatan intravena menjadi pilihan dibandingan obat inhalasi. ${ }^{11-13}$ Secara umum target manajemen anestesi adalah menjaga ventilasi. Karena cadangan oksigen ibu yang menurun selama kehamilan penurunan saturasi akan terjadi begitu pasien apneu. Ventilator mekanik harus disesuaikan untuk menjaga $\mathrm{PCO}_{2}$ 30-32 mmHg. ${ }^{14}$ Intubasi dilakukan dengan rapid sequence induction (RSI) dan setelah pipa endotrakheal masuk dijaga tekanan intracranial dengan menggunakan rumatan rocuronium 0,5 $\mathrm{mg} / \mathrm{kgbb}$ dan fentanyl 1 micro/kgbb. Gas yang menjadi pilihan yaitu sevoflurane 1,5-2 minimal alveolar concentration (MAC) karena tidak mengiritasi jalan nafas dan tidak mempengaruhi tekanan darah. Penanganan nyeri pasca operasi menggunakan opioid dalam pasien ini dipilih fentanyl $1 \mathrm{micro} / \mathrm{kgbb}$ serta parasetamol $1 \mathrm{gram} / 8$ jam intravena.

\section{Simpulan}

Pasien eklampsia dan asma akut berat adalah kondisi serius dan mengancam jiwa yang dihadapi oleh wanita hamil terutama masalah jalan nafas dan terjadinya hipoksia baik pada ibu maupun bayi. Diagnosis dini dan pengobatan yang cepat melalui tim multidisiplin dalam pengaturan intensive care unit (ICU) dapat mencegah komplikasi dan mengurangi morbiditas dan mortalitas. Penyebab paling umum untuk intubasi dan ventilasi mekanik karena kegagalan pernafasan akibat edema saluran nafas bagian atas, ketidakstabilan hemodinamik akibat kejang dan anemia. Pasien dengan asma akut berat membutuhkan ventilasi yang optimal. Penanganan anestesi yang efektif pada pasien ini akan meningkatkan survival serta memberikan prognosis yang lebih baik.

\section{Daftar Pustaka}

1. Chestnut DH. Chestnut's Obstetric Anesthesia: Principles and Practice, 5 th ed. Philadelphia: Elsevier; 2015, 521, 532-33, 2056-62.

2. Maternal Mortality [database on the internet]. c2010 - [cited 2011 Oct 20]. Available from: http://www.who.int/mediacentre/factsheets/ fs $348 / \mathrm{en} /$.

3. Lindheimer MD, Taler SJ, Cunningham FG. Hipertension in pregnancy. Journal of the American Society of Hypertension. 2008; 9 (3) : 119-23.

4. Sirait AM. Prevalensi hipertensi pada kehamilan di Indonesia dan berbagai faktor yang berhubungan. Buletin Penelitian Sistem Kesehatan.2012;15(2):103-9. 
5. Global Initiative for Asthma (GINA): Global strategy for asthma management and prevention. 2009. Available at: http://www. ginasthma. com Accessed July 15, 2010.

6. Fynefaceogan S. Anesthesia for cesarean section. In: Cesarean delivery. IntechOpen. 2012.

7. Kant S, Ojha S. Management of asthma in pregnancy. Indian J Allergy Asthma Immunol. 2006 ; 20 (2): 117-12.

8. Morgan GE. Maternal \& fetal physiology \& anesthesia. In : Morgan GE, editors. Clinical Anesthesiology. 3rd ed. New York: Mc Graw Hill; 2002, 804-13.

9. Yarnell RW. Emergency surgery during pregnancy. Available from: URL:http://www. anesthesia.org/winterlude/w195/w195_6. html. Accessed november 12,2006.

10. Dixon JM, Gunning KEJ.The incidence of
ARDS interim result of the east anglian ARDS registry. Critical Care .2000; 4(Supp1 1) P130.

11. Acute Respiratory Distress Syndrome Treatment. Last Update 17 May 2011. WWW. HealthCommunities.com.

12. Afolabi B, Lesi FE. Regional versus general anaesthesia for caesarean section. Cochrane Database of Systematic Reviews.2012.

13. Moodley J, Jjuuko G, Rout C. Epidural compared with general anesthesia for cesarean delivery in conscious women with eclampsia. British Journal of Obstetric and Gynecology. 2001;108:378-82.

14. Parungo CP, Brooks DL. The pregnant surgical patients: discussion. Available from: URL : http://www.medscape.com/ viewarticle/52442. Accessed November 12, 2006. 